\title{
Desporto, Paideia e a Não Dualidade
}

\author{
Alberto de Oliveira Monteiro*
}

\begin{abstract}
Resumo: O presente ensaio tem a intenção de apresentar uma discussão, a partir das contribuições conceituais e filosóficas (oriental e ocidental), a respeito das esferas da dualidade e da não dualidade: refletir, a partir de uma visão tríade circunscrita nos diferentes princípios filosóficos, sobre as ideias e os conceitos que orientam para a Unidade. A filosofia platônico-socrática é a base das nossas meditações e, particularmente, dos indícios de Unidade junto à Paideia. Sugerimos a educação desportiva, por intermédio do seu extrato simbólico, como uma prática que pode construir uma Unidade possível.

Palavras-chave: Esportes. Filosofia. Educação.
\end{abstract}

\section{INTRODUÇÃO}

"Quem for capaz de ver a totalidade é um filósofo; quem não, não..."

Platão ${ }^{1}$

Volta e meia deparamo-nos com algumas inquietações vindas do quadrante científico-intelectual que apontam para os cuidados referentes à prática da dualidade. Naturalmente é necessário, em todas as esferas, encontrar meios pelos quais se deva atenuar a prática dual e, ao mesmo tempo, envidar esforços intelectuais e práticos em busca da ideia e do ideal de Unidade do ser humano.

O nosso movimento cultural está particularmente distante da assunção, na sua essência, de uma visão integral e unitária do homem: nessa matéria há uma paradoxal equidistância entre o discurso e a prática. $\mathrm{O}$ termo dualista tem sido relacionado indiscriminadamente a vários personagens históricos e às religiões maniqueístas. Há

\footnotetext{
* Escola de Educação Física da Universidade Federal do Rio Grande do Sul (UFRGS). Porto Alegre, RS, Brasil. E-mail: 00006908@ufrgs.br

1 "Quien sea capaz de ver la totalidad es filósofo, quien no, no...". Extraído da obra de Reale e Antiseri (1991)
} 


\section{Antifor Originais}

também uma profusão de conceitos vinculados às áreas filosófica, epistemológica, religiosa, cartesiana e outras. Churchland (2004) adverte que o "dualismo não é a concepção mais amplamente difundida em meio à comunidade científica e filosófica hoje em dia, mas é a teoria da mente mais comum às pessoas em geral". Por outro lado, a conceituação do não dualismo torna-se ainda mais problemática, especialmente em se tratando do dia-a-dia. Portanto, o fato de descobrirmos o problema não significa resolvê-lo.

A percepção dualista encontra-se mais próxima das pessoas, porque o nosso universo - multiverso - é constituído de nomes e formas, espaço e tempo, luz e sombra, causa e efeito, que se encontram articulados às inevitáveis experiências e consequências de viver neste mundo. A própria diversidade na manifestação da natureza, a menos que seja olhada pela perspectiva dialética, se dá a partir da sua organização, cuja projeção contempla, entre outros, o dia e a noite, o calor e o frio, a altitude e a planura, o amargo e o doce e as suas constantes oscilações. Na física quântica, o elétron, muitas vezes, é descrito na sua dualidade onda-partícula. Essas não seriam revelações de uma dualidade objetiva? Seriam as formas pelas quais a mente humana se organiza, ou se projeta, para lidar com o universo material? Como e quando o universo se articula com o Uno-nãodual? Qual o modelo de formação que se preocupa com a educação para a Unidade do ser humano? O desporto pode ser um elemento integrador das diferentes dimensões humanas?

Embora reconhecendo que existem outras maneiras de abordar esse assunto, é nossa intenção, a partir das contribuições tanto da filosofia oriental como da ocidental, propor uma reflexão que possa demonstrar que ambas convergem para uma mesma visão sobre a não dualidade e a dualidade. Em seguida, teremos a oportunidade de refletir sobre a perspectiva de Unidade apresentada na filosofia platônico-socrática, registrar o sentido sintetizador e unificador da Paideia, e apontar o desporto como extraordinário meio pedagógico para se atingir o fim de uma Unidade possível.

Movimento, Porto Alegre, v. 17, n. 01, p. 213-235, janeiro/março de 2011. 


\section{RefleXÃo ConCEItUAL}

Segundo o dicionário Oxford de filosofia (BLAKBURN, 1997, p. 108), o dualismo é qualquer "teoria que postule dois gêneros de coisas num certo domínio". O exemplo mais famoso dessa teoria é o dualismo judaico-cristão, onde o espírito prevalece sobre o corpo. Já o dualismo cartesiano é aquele no qual a mente e o corpo são duas substâncias separadas. O eu está ligado a um corpo específico, mas é auto-suficiente e capaz de existência independente; nesse sistema o que vigora é uma relação entre o corpo, a mente e Deus. O não dualismo, ou monismo, é a teoria que vê um onde o dualismo vê dois e, por isso, contrasta com o dualismo mente-corpo, matéria-espírito e outros. Em se tratando do idealismo absoluto, temos a doutrina de uma única realidade e que consiste nas modificações do Absoluto (BLACKBURN, 1997).

Para nós, há uma significativa diferença entre dualismo e dualidade; e esperamos que as palavras de Boff (2000a, p. 80) possam esclarecer essa questão: "o dualismo considera as coisas separadas, enquanto que a dualidade as vê juntas como dimensões da mesma e única realidade". Se aceitarmos esse esclarecimento, podemos intuir que muito do que foi objeto da nossa discussão (reflexão preliminar) pode ser considerado algo relacionado com uma visão voltada para o entendimento e a possibilidade de uma interpretação que considere não apenas o juízo equidistante entre o dualismo e o não dualismo, mas, também, que a expressão dualidade está ligada à estrutura de conhecimento que possibilita, além da superação maniqueísta, a manifestação da própria Unidade.

Nas Upanishades ${ }^{2}$ encontramos a origem das ideias de du-

\footnotetext{
${ }^{2}$ Para esse texto, a citação às Upanishades está perfeitamente ligada aos ideais filosóficos, desde que se entenda a filosofia como o exercício reflexivo sobre as finalidades últimas da existência humana. "Ainda hoje parece óbvio que a filosofia deve [...] partir e falar de uma realidade exterior a ela: é a filosofia das ciências, do direito, da linguagem [...], mas quase nunca, sob pena de parecer ridícula ou dogmática, amor à sabedoria" (FERRY, 2007, p. 89). Segundo Tinôco (2009, p. 17) "As Upanishads são consideradas pela tradição indiana a essência filosófica da antiga sabedoria dos Vedas". Blackburn (1997, p. 396), em seu Dicionário de Filosofia, considera que as Upanishads pertencem à "Coletânea de versos filosóficos que concluem os Vedas, constituindo o principal comentário filosófico original às escrituras hindus". Essa filosofia possui uma posição radical na defesa da Não Dualidade. A sabedoria védica foi passada, através dos séculos, pela palavra dos mestres hindus. Aquilo que se procurou expor pelas palavras ultrapassa em muito

Wovimento, Porto Alegre, v. 17, n. 01, p. 213-35, janeiro/março de 2011.
} 
alidade (dvaita) e não dualidade (advaita), quando estudamos os conceitos de Brahman e de Atman. Na raiz dos conceitos de dualidade e de não dualidade está o entendimento sobre o significado da ideia de Brahman-Atman. Brahman é Não Dualidade, um Monismo puro, aquilo que é único e indiviso, e no qual não existem opostos (SANFORD, 1998; TILAK, [197?]). Atman é a alma individual, "é o princípio universal que é a base e a origem de tudo que parece ser alma individual, ou eu" (SANFORD, 1998, p. 34). Conforme as escrituras hinduístas, Jiva é a parte que vigora no Atman, que é considerada a alma, cuja manifestação é o próprio Uno e Indivisível Brahman: o criador e o sustentador de todo universo visível e invisível.

Os seres humanos compartilham a natureza de Atman. Quando realizamos esse ideal, dizemos EU SOU! Cristo disse "Eu Sou o Caminho, Eu Sou a Verdade, Eu Sou a Vida" (São João, 14, 6). Eu digo EU SOU quando tenho plena consciência de que sou aquele que é: o autoconhecimento. Sócrates, por isso, insistia no dito délfico "Conhece-te a ti mesmo".

De igual envergadura, na tradição chinesa deparamo-nos com um princípio, ao mesmo tempo, unificador e harmonizador da natureza (incluindo o homem), o Tao: do "Tao nasce o Um; do Um nasce o Dois; do Dois nasce o Três; e do Três nascem as dez mil coisas" (LAO-TSÉ, 2001, cap. 42). Desse modo, o Tao representa a Unidade, assim como Brahman (ou o Absoluto, Deus, Ser, o Eterno). Da Unidade nascem dois outros princípios - o yin e o yang - e depois todo o universo de manifestações. Ou seja, mais uma vez, na origem das sabedorias antigas, a manifestação dual é a extensão visível e invisível, material e imaterial, física e espiritual da própria Unidade. Atentemos para o que nos relata Watts $(1975$, p. 54): o "yin-yang não é o que ordinariamente denominaríamos dualismo mas, ao contrário, uma dualidade explícita que expressa uma unidade implícita". A objetividade leva-nos costumeiramente a entender que o mundo não é o da Existência verdadeira, indivisível e imutável. Aquilo que

a expressão verbal. A busca interior pelo sentido da vida e a sua manifestação em cada ação exterior fazem das Upanishads um rico manancial de expressão filosófica.

Movimento, Porto Alegre, v. 17, n. 01, p. 213-235, janeiro/março de 2011. 
percebemos é um mundo de entidades (aparentemente) diferentes no qual acreditamos ver seres e objetos separados e com formas de vida diversas e, muitas vezes, antagônicas; nele acreditamos não haver possibilidade de Unidade, porque todos parecem ter a sua própria existência (SANFORD, 1998)³. Uma coisa é falar sobre a não dualidade; outra coisa é a penetração no seu mistério. $O$ enigma do funcionamento de que Atmam é Brahman - assim como o Tao é yin e yang - não pode ser explicado por meras palavras. A não dualidade é uma dimensão, não uma teoria, onde o conhecimento ordinário não consegue penetrar, pois, onde há o que ser conhecido, há também um conhecedor e, assim, há dualidade.

Ao longo do processo civilizatório, o homem construiu uma trajetória em que, conforme Eliade (2001), foi gradativamente caminhando do sagrado na direção do profano. O mundo arcaico era povoado por deuses, heróis, mitos e semideuses, e traduzia, com isso, a Unidade sagrada de todas as potências humanas. O processo de dessacralização da morada humana - cujo início se deu com a transformação do mundo provocada pela sociedade industrial e pelo pensamento científico, em especial com as descobertas da Física e da Química (ELIADE, 2001) - levou-nos à posição de conquistadores, ao invés de integradores das diversas dimensões do homem.

\section{Para alÉm do duAlismo}

Não é difícil notar que muitos não atribuem a visão do dualismo a uma luta (cósmica) do homem com o seu destino e que, possivelmente por causa disso, muitas vezes atribuem a pecha dualista e racionalista a um rol de instituições e de pensadores. Estamos de acordo com Mário Ferreira Santos (2001, p. 132) quando ele aponta a causa dessas atitudes: "A mente humana separa e exclui para compreender e, sobretudo, para classificar". Por isso, ponderamos que os traços, maiores ou menores, da cultura dual podem ser notados em vários textos e correntes de diferentes matizes do pensamento.

\footnotetext{
${ }^{3}$ A possibilidade de integração e de Unidade se dá quando nos damos conta de que, por exemplo, o dia nasce da noite do mesmo modo que a noite também nasce do dia: luz e trevas sucedem-se, dando uma origem às outras.
}

Movimento, Porto Alegre, v. 17, n. 01, p. 213-35, janeiro/março de 2011. 
Devemos, ainda, realizar duas rápidas observações: a) como a visão dual parece ter um caráter universal e, portanto, ser mais próxima da experiência humana, precisamos concentrar-nos e pôr em relevo, sem preconceitos, as ideias, os ideais, as postulações e as utopias que busquem o entendimento da identidade e da Unidade humanas; b) é preciso deixar claro que, conforme Campbell (2008), quando aludimos para as teses de dualismo e não dualismo, estamos evidenciando categorias do pensamento.O mesmo autor sustenta que a Unidade é expressada metaforicamente por meio das palavras Deus, Brahman, Tao, o Eterno, o Ser ou qualquer alusão ao divino. $\mathrm{O}$ sentido dessas palavras é dar identidade àquilo que, de alguma maneira, atinge e desperta, em nós, a própria Unidade: o encontro com uma "sabedoria que ultrapassa de longe a filosofia" (FERRY, 2007, p. 60). Nessa premissa, concebemos que a Unidade, sua existência, sua essência e sua identificação com o mundo humano e material são modos de desmembrar, para perceber, o que é o Uno na diversidade.

Platão (TIMEU, 28c) confidencia que é difícil encontrar o criador e pai deste universo; e, tendo-o encontrado, é impossível revelá-lo a todos. Diante do exposto, consideramos que a alternativa é apreciarmos, junto com Bento (1998), que, nesse caso, é preciso esgotar o campo do possível, seguindo a atitude democrática de aceitar a dialética da Unidade na diversidade.

\section{A FILOSOFIA PLATÔNICO-SOCRÁTICA: UMA PROPOSTA DE UNIDADE}

Uma importante parcela de estudiosos da cultura ocidental, ao descrever a obra de Platão, tece, entre outras acentuações, algumas observações como: Platão queria demonstrar que "as idéias não são minhas ou suas, não pertencem a este ou àquele pensador. As idéias estão aí, sendo pensadas, a serem pensadas, antes de nascermos e depois de morrermos" (WATANABE, 2006, p. 105); "Platão, ao contrário, [...], não teme colocar suas próprias teses em profundas dificuldades. E essa talvez seja a verdadeira lição de humildade filosófica posta em prática nos Diálogos..." (WATANABE, 2006, p.47; SANTOS, M. F., 2001); “[...] o que caracterizava Platão era o

Movimento, Porto Alegre, v. 17, n. 01, p. 213-235, janeiro/março de 2011. 
fato de lhe interessar mais expor a filosofia e a sua essência através do movimento vivo da dialética do que a forma de um sistema dogmático acabado" (JAEGER, 2003, p. 583); "Sócrates é incapaz de "aceitar qualquer dogma"' (JAEGER, 2003, p. 580); e, finalmente, o mesmo autor (JAEGER, 2003, p. 579-580) apresenta-nos a sentença "Sócrates possuía ao mesmo tempo, além do dom de saber, [...] aquele dom instintivo cuja falta verificamos tão frequentemente no racionalismo". Por essas reflexões, podemos dizer que uma das obras que mais claramente se opuseram a qualquer tipo de sectarismo, relativismo, dogmatismo e outros ismos foi precisamente a filosofia platônico-socrática.

Estudiosos alimentam a tese de que Platão teria subdividido o mundo em mundo sensível e mundo das idéias: é interessante que se discuta esse assunto. Analisamos que o problema central das designações em tela está relacionado à hermenêutica: ler um texto é interpretá-lo, e nossa interpretação não estaria livre da subjetividade e da distância do que teria sido a expressão e a intenção de Platão, nem estaria isento de equívocos com relação à compreensão do próprio texto grego arcaico (REIS, 2007; WATANABE, 2006), cuja essência era pagã.

Observemos, com Jaeger (2003, p. 534), a visão de Unidade no pensamento de Sócrates: a "alma só pode compreender-se com acerto se for concebida com o corpo, mas ambos com dois aspectos distintos da mesma natureza humana..." e complementa: "Mas assim como pela existência do corpo e da alma [...] se espiritualiza esta natureza física, assim como reflui sobre a alma algo da própria existência física". Em Xenofonte (I, 4, 8) se encontra que Sócrates não entendia que o homem estivesse, por causa da composição corpo e alma, separado do restante do mundo vivo.

Nos textos de Platão, como no Timeu, podemos ver a sua apreciação unitária: "o paradigma é um ser vivo eterno, empreendeu tornar este universo, na medida do possível, igualmente eterno" (37d). Mais adiante, o filósofo explica o ser eterno desta maneira: "produziu uma imagem eterna da eternidade que permanece na unidade [...], e que é aquilo a que chamamos tempo" (37d); e conclui:

Movimento, Porto Alegre, v. 17, n. 01, p. 213-35, janeiro/março de 2011. 
“dizemos que foi, que é e que será, quando 'é' é a única expressão que se lhe aplica a verdade, enquanto 'era' e 'será' são expressões que convêm àquilo que se gera e se move no tempo - porque são ambos movimento" (37e-38a). Aqui a palavra "é", naturalmente, aplica-se ao ser que é eterno. Para Platão há uma identidade última entre o Ser e a diversidade expressa no mundo espaço-temporal (do mesmo modo que nas filosofias orientais), ou seja, Platão não pensa no mundo sensível fora do próprio Ser: "Ora, o deus faz-nos sinal de que, de acordo com o argumento verossímil, há um único mundo" (TIMEU, 55d). Portanto, dizer que as Ideias estão num determinado lugar deste universo e estão em oposição ao 'mundo' sensível é, na opinião de autores como Dulce Reis (2007) e Mário Ferreira dos Santos (2001), uma forma de deturpação do texto platônico, além de ofender e embasar sua filosofia.

No Fredo, o ser vivente é constituído do conjunto alma e corpo, e a ideia de divindade é aquela que fosse como um ser vivente que não morre, com alma por um lado e corpo por outro, mas unidos eternamente pela natureza (246, c-d). Quanto às considerações sobre a interpretação de que o corpo é o túmulo da alma, Dulce Reis (2007) argumenta que a palavra grega séma, comumente traduzida/ interpretada como 'túmulo', pode, igualmente, ter outros significados como 'signo', 'marca', isto é, sem qualquer caráter negativo e, sim, compreendendo o corpo vivo como signo da alma no homem encarnado. Em concordância com essa versão, Sócrates avaliava que o ser físico, juntamente com a expressão dos movimentos, é o espelho do seu interior e de suas qualidades, resplandecendo o seu conteúdo moral e a sua interioridade (XENOFONTE, III, 10, 1-5). É na fundamentação dialética expressa pela Paideia platônico-socrática que se pode compreender a composição corpo e alma como expressão e representação do universo visível e invisível, material e imaterial, e interno e externo. E isso, do ponto de vista simbólico, possui uma importância pedagógica decisiva para o desporto e para a Educação Física; pois os gregos, naquela época, só poderiam considerar os desportos e a Educação Física como uma face imprescindível da educação, uma vez que nunca lhes poderia ocorrer exercitar qualquer parte do ser que não fosse o homem todo (KITTO, 1990). E, no desporto, na intimidade e vontade humanas, há uma constelação de

Movimento, Porto Alegre, v. 17, n. 01, p. 213-235, janeiro/março de 2011. 
valores; e, ao mesmo tempo, desenvolve-se um processo educativocultural (Paideia) que é responsável por acionar um princípio e um ideal que nos levem à tão almejada Unidade.

\section{PAIDEIA: A ETERnA BUSCA DA UNIDADE}

A palavra Paideia, que inicialmente era ligada aos cuidados infantis, a partir da concepção platônico-socrática, conheceu a ideia de elevação do homem na sua expressão unitária. Para Jaeger (2003), a Paideia é uma forma interior de vida, a sua existência espiritual que se manifesta em todos os seus atos, portanto, enobrecendo a cultura.

Como a aretê é o principal conteúdo da Paideia, em algumas ocasiões, nos diálogos de Platão, vamos ver que Sócrates esforçase para provar a Unidade das aretai. No Protágoras, notamos a essência do projeto educativo-formativo de cultivo da Unidade, quando Sócrates apela à reflexão dialética a fim de levar o sofista do diálogo a concluir pela Unidade das aretai: "a virtude [aretê] é só uma, e a justiça, a prudência e a piedade partes dela, ou são estas virtudes [aretai] apenas nomes diferentes para exprimir a mesma coisa" (PROTÁGORAS, 329c). Com essa proposta em mente, ele estabelece relações entre as diferentes virtudes, como forma de demonstrar a Unidade delas; e o exemplo mais significativo é o da relação da valentia e do saber (PROTÁGORAS, 360c). Na Paideia do mestre da maiêutica, não há lugar para a fragmentação, como aquela praticada pelos tempos atuais, pois ela se apoia na Unidade do conhecimento do Bem (Ser) na qual, em última instância, sempre se reduzem o estudo e a prática de todas e de cada uma das aretai. Esse conhecimento do Bem é, para Jaeger (2003), algo mais amplo que a valentia, a justiça e a comiseração: é na aretê das aretai que se revela a Unidade nas diversas virtudes.

Esse modelo de educação e de formação visava a unir todas as tarefas humanas (política, intelectual, médica, artística, atlética e as demais) numa única e elevada aretê; o conhecimento e a prática do Bem. Como nos revela Jaeger (2003, p. 876): "Deus é a medida de todas as coisas; e o é porque é o Bem”. E se Ele é o próprio Bem,

Movimento, Porto Alegre, v. 17, n. 01, p. 213-35, janeiro/março de 2011. 
"então a suprema arete acessível ao Homem constitui um processo de aproximação de Deus, pois, [nos diálogos de Platão] as diversas virtudes (aretai) têm como fundamento comum o Bem-em-si ou o próprio Bem" (JAEGER, 2003, p. 878).

A construção do saber e a sua realização prática constituíam a base que legitimava a Paideia helênica como uma educação que permitia a cada um realizar a sua natureza verdadeiramente humana no seio daquela cultura: A humanitas é a humanidade do homem, ou seja, a sua essência, o seu ser próprio (PATRÍCIO, 2005; SANTOS, M. F., 2001). Essa realização processava-se junto à pólis (a relação social), a qual ensinava o que no cidadão era a estrutura física, a política, o militar, o exercício, a ética, o espiritual, ou seja, ensinava, numa única palavra, o que no cidadão era ser humano: ensinava a humanitas. Humanitas: o telos da aretê (PATRÍCIO, 2005).

O mundo inteligível oferece-nos inúmeras sensações de certezas e, paradoxalmente, inseguranças. A superação desse contrassenso pode ser conquistada a partir da filosofia da Paideia, quando entendemos que o dinamismo e a efemeridade dos conhecimentos temporais são como etapas de desenvolvimento, gradativas até o princípio universal: "É este o método de conhecimento que é o verdadeiro logos, o logos puro" (JAEGER, 2003, p. 881). Esse logos é inapropriado ao campo das opiniões e, ao contrário, é adequado ao conhecimento e à investigação do reino da verdade (JAEGER, 2003): a esfera em que se processa a Paideia. Nesse âmbito, o Logos puro é fruto, além da dimensão racional, do amor e da ação perfeitos, pois nenhum Logos, na perspectiva da Paideia, pode ser encontrado apenas na perspectiva unidirecional. Essa é a moldura por onde se retrata a ponderação de que o conhecimento científico é meio, o conhecimento tecnológico é meio, o conhecimento teórico é meio. Qualquer conhecimento dessa natureza é conhecimento-meio. Ou, como queria Boaventura Santos (2000), todo conhecimento é autoconhecimento. A interrogação é esta: como se atinge e qual é o conhecimento-fim? O homem realiza-se como homem na medida em que atua numa determinada circunstância: na família, na sociedade, no mundo. A Paideia grega aconselha que se aja de maneira correta, fazendo bem aquilo que se faz, quer seja como cientista,

Movimento, Porto Alegre, v. 17, n. 01, p. 213-235, janeiro/março de 2011. 
técnico, professor, sapateiro, desportista, irmão, amigo, esposa ou qualquer outra forma de expressão humana, pois cada ato é válido na medida em que é útil; e cada ação, para ser boa, precisa resultar da inteireza do ser humano (ADORNO, 2002). O conhecimento é fim na medida em que o indivíduo realiza a si próprio e aos outros de forma justa e em conjunto, levando ao êxito pessoal e coletivo. Em outras palavras, no seu âmago, é aquilo que trata da nossa essência (Conhece-te a ti mesmo): conhecimento da Pessoa humana, investigação sobre o espírito e exame sobre a consciência do Ser. O conhecimento-fim é a humildade da sabedoria de que nada se sabe e, ao mesmo tempo, o interesse investigativo diante de um saber, ou conhecimento, que ainda está por ser elucidado, mas pelo qual vale a pena esforçar-se para conhecer, porque a investigação profunda é o projeto de toda uma vida.

Nesse ponto, é interessante destacar que a atividade desportiva ocupava um lugar central na Paideia Helênica e, por conseguinte, na vida dos gregos. Os filósofos clássicos sentiam-se à vontade nos locais em que imperavam os exercícios atléticos. Conforme Jaeger (2003), a Paideia platônico-socrática tinha a vocação de combinar harmonicamente as aretai do corpo, da saúde, da beleza, da força e da destreza com as aretai da alma, da comiseração, da valentia, da moderação e da justiça; todas elas proclamavam por igual simetria do universo.

\section{EdUCAÇÃo (PAIDEIA) DESPORTIVA: A UNIDADE POSSÍVEL A PARTIR DO SIMBOLISMO}

Conta a história que Pitágoras, em certa ocasião do século V a.C., distinguia três grupos de pessoas que iam aos Jogos Olímpicos: as que iam lá para servir aos seus próprios interesses (comerciantes, negociantes e outros), sem qualquer interesse sobre aquela atividade; as que iam lá para competir e alcançar a glória pela exposição da sua aretê (atletas, músicos, poetas e outros); e as que estavam lá para celebrar e contemplar a expressão do desempenho humano como um valor divino. Essas últimas eram, para Pitágoras, como os filósofos que

Movimento, Porto Alegre, v. 17, n. 01, p. 213-35, janeiro/março de 2011. 
viam nos jogos uma ótima oportunidade estudar as razões, perceber as relações internas e discernir sobre os sentidos da sua prática.

Essas considerações depreendem-se do fato, entre outros tantos, de que Platão demonstrava seu cuidado com a educação infantil, chamando a atenção para o caráter educativo do jogo para as crianças (Leis, 794a). Na República (452b), a preocupação era que os idosos fizessem exercícios físicos. O desporto era um elemento de formação e de cultura patrocinado pela ação corporal para todas as idades e para todos os males, pois, conforme decretou Sócrates, "é sumamente deplorável envelhecer em meio ao puro descuido, sem perceber em que tipo de ser humano é possível se tornar promovendo a força e a beleza físicas em seu grau máximo" (XENOFONTE, III, 12, 8).

Ao longo de mais de 28 séculos, o desporto enfrentou diversos desafios: alguns imperadores, reis, déspotas, religiosos e outros foram responsáveis pela proibição da sua prática.

Mas, apesar dos reptos, no desporto há algo que se configura como incomum, extraordinário e genuinamente Belo - e, por isso mesmo, sujeito a pesquisa simbólica.

Essa tarefa humana conseguiu impor seus ideais de educação, de glória e de exaltação da ação humana. E foi assim, ao longo dos anos, que vimos, por exemplo, como Pierre de Coubertin, inspirado pelos ideais, princípios e valores da Grécia Clássica, fez ressurgir os Jogos Olímpicos; e como Rousseau, reconhecendo a importância do legado do desporto grego, demarcou a pedagogia da Educação Física. Garcia (2006) lembra que o desporto, no período chamado Guerra Fria, ajudou a evitar conflitos entre as grandes nações; e Costa (1997) salienta que no desporto há sempre algo para ser estudado, encontrado e, uma vez desvendado, praticado; pode mesmo ser considerado como utópico. Bento (2006) define-o com a seguinte reflexão: o desporto é concebido e interpretado como um fenômeno polissêmico e uma realidade polimórfica, múltipla e não singular. Ele se baseia num entendimento plural e num conceito representativo, agregador, sintetizador e unificador de dimensões biológicas, físicas, motoras, lúdicas, técnicas e táticas, culturais, mentais, espirituais, psicológicas, sociais e afetivas. $\mathrm{O}$ desporto possui sentidos e sig-

Movimento, Porto Alegre, v. 17, n. 01, p. 213-235, janeiro/março de 2011. 
nificados, princípios e valores, normas e regras, possibilidades e realizações. Por isso, ele pode resgatar, no seio da nossa sociedade atual, os ideais de unidade e diversidade, de indivíduo e sociedade, de sensibilidade e racionalidade, de imanência e transcendência.

O desporto é um evento eminentemente cultural e é assim por ser um espaço de manifestação simbólica onde o indivíduo, assim como nas artes, projeta, de modo não verbal, o seu interior, a sua natureza, a identidade e a sua integralidade: uma possibilidade real de Unidade do ativo e da contemplação. Por isso, os orientais consideram que, assim como também era para os gregos antigos, o processo desportivo possui, antes de tudo, um significado sagrado e místico; e a sua prática é a senda, a direção para a realização espiritual. Justamente por isso, segundo Kushner (1988), os japoneses pospõem o sufixo dô aos nomes das artes marciais. Esse termo é uma tradução japonesa da palavra chinesa Tao, que significa Caminho. Com essa forma de ver o desporto (como Caminho), intuímos que ele proporciona condições para o progresso a partir da força do movimento e da experiência contemplativa. A vida do espírito manifesta-se a partir do caminho, caminhando em cada ação, em cada ato humano de excelência, portanto, ato do espírito (VAZ, 2004). É "não exercitar a alma sem o corpo, nem o corpo sem a alma" (PLATÃO, Timeu, 88b); dessa forma o microcosmo humano, pela mão do desporto, pode imitar a Unidade do universo, na qual o cosmos e o caos equilibram-se com vistas à construção $\mathrm{e}$ à reconstrução do próprio universo.

Diante dessa possibilidade, seja em que espaço do mundo estejamos, consideramos que o autoconhecimento é a essência do microuniverso humano. Desse modo, o conhecer a si mesmo, realizado pela inspiração da prática desportiva, é uma etapa capaz de ser conquistada quando se verifica que o treino desportivo permite que o praticante melhor se conheça a partir da responsabilidade pelo seu corpo, pelos seus sentimentos e pelos seus limites e possibilidades. Esse modo de se ver, de se contatar e de se conhecer tem repercussões sobre o modo como a pessoa dirige a sua vida como um todo: a cultura desportiva é também uma educação moral, que toca e disciplina a vontade (FERNANDES, 2000).

Wovimento, Porto Alegre, v. 17, n. 01, p. 213-35, janeiro/março de 2011. 
Há um momento em que a vitória desportiva apresenta-se, tanto para o atleta como para o espectador, como uma imagem de alegria e de arrebatamento inigualáveis. Boff (2000b, p. 44) relata que conhece "um torcedor que antes de um grande jogo [...]. Quando chega o dia compra antecipadamente a entrada, vai ao estádio e ninguém o segura. Ele freme, ele treme e na hora do gol experimenta um salto para a transcendência. É o delírio, é o grito, é o abraço, é o gozo, é o êxtase". O mesmo ocorre com o atleta desportivo que, num momento de extrema alegria, agradece aos deuses e enche-se de graças. Em trabalhos empíricos, verificamos que, ao serem consultados sobre esse momento, os atletas e espectadores dizem que "não dá para explicar". Curiosamente, os textos taoístas e huiduístas dizem que, quando se fala sobre o Uno, não se está falando do verdadeiro Uno, pois ele é inexplicável. Como explicar algo que surge da arte imaginativa e criativa, expressa pelo domínio do corpo e dos sentidos, e com vistas a situar a beleza, mesmo que os desportistas não saibam, num patamar divino? $\mathrm{O}$ desporto, de alguma maneira, registra assim um ponto de interação com a fórmula Não Dual.

Para a civilização ocidental, particularmente para os gregos antigos, o universo surgiu de acordo com a narração de Hesíodo (séc. VIII a.C.). Ele conta que, no início de tudo, só havia o caos (desequilíbrio, desordem, desarmonia, o abismo e a treva). O que ali prevalecia eram as forças titânicas.

Diante da mais completa desorganização, Zeus liderou o panteão divino para lutar contra as forças caóticas; e depois de um longo período de enfrentamento agônico ${ }^{4}$, o embate terminou com a vitória dos deuses. Foi, assim, instaurado o cosmos (equilíbrio, organização, justiça e amor): o Universo.

Do ponto de vista geral, essa é uma história mitológica que, desde que o homem existe, se renova todos os dias em nossas vidas:

\footnotetext{
${ }^{4} \mathrm{O}$ 'agon', normalmente, é um termo que se vincula à assembleia, à luta, ao combate, ao debate, à convivência no coletivo, bem como ao senso estético (e portanto, ético e, consequentemente, político). Entretanto, a cultura grega antiga era permeada pela energia agônica: nos textos de Hesíodo e Homero, o espírito agônico surge de modo transparente junto às ações dos deuses, dos heróis e dos atletas (guerreiros que competiam nos jogos desportivos). O espírito agônico ('agon') tem uma presença influente na luta que cada indivíduo empreende para conquistar as vitórias sobre si mesmo.
}

Movimento, Porto Alegre, v. 17, n. 01, p. 213-235, janeiro/março de 2011. 
uma metáfora que ajuda despertar a profunda consciência circunscrita no ato de viver e de conviver. O cenário onde ocorre o duelo entre os deuses e os titãs está no mundo que existe dentro de cada um de nós! Essa experiência mágica é algo pessoal e intransferível!

E, do ponto de vista especifico, é na prática desportiva que surge a reprodução do enigma da formação do universo, pois é no interior do espaço desportivo que aprendemos a enfrentar diuturnamente as forças desafiadoras que insistem em querer calar o apreço à superação, à competência, ao talento e à vontade. A essência desse apreço não pode ser captada sem a leitura apurada dos movimentos desportivos: um universo simbólico em que o homem está por inteiro na luta contra o seu destino. Urbano (2000, p. 183) discerniu que a "corrida, o combate, a prova que coloca o homem contra o outro homem, a competir pela vitória, aquilo que chamamos de espírito agónico [...], é decerto mais do que uma competição"; e acrescentou que "É a luta do homem para se superar a si mesmo, para superar os limites da sua caducidade. Por isso, nós encontramos ao longo da história e das realizações humanas a força deste espírito".

É nesse enfoque que a tarefa educativa e desportiva possui um alto significado de cultura: a luta dos deuses para enfrentar o caos e a luta do homem para triunfar sobre si mesmo são a expressão do 'agon' que é travado tanto no plano divino como no humano.

O caráter simbólico da cultura (Paideia) desportiva manifestase na possibilidade de reconhecermos a profunda conformidade entre a saga dos desportistas (de alto nível ou não), a epopeia dos heróis (pessoas que lutam melhorar a vida) e a vida dos deuses. Senão vejamos: a história do desportista, assim como a vida do espírito, significa tentar uma vez, outra vez, quantas vezes forem necessárias, sem desânimo, sem cansaço, sem mau humor, até que o obstáculo transforme-se em troféu (FERNÁNDEZ, 2004). Sendo assim, podemos levantar as seguintes indagações: na competição desportiva, como na vida comum, onde está o adversário que interessa vencer? Onde está a prova que se deve superar? Onde se encontra a medalha que precisamos conquistar? Resposta: na verdade, em nós mesmos! E a superação desportiva é símbolo que denota a possibilidade de nos esforçarmos para combater os desejos desenfreados, os vícios, a

Movimento, Porto Alegre, v. 17, n. 01, p. 213-35, janeiro/março de 2011. 
fadiga tolerável, o medo paralisante e os sentimentos de incapacidade que formigam na nossa existência.

Conforme Huizinga (2003), no desporto há qualquer coisa em jogo que transcende as necessidades imediatas da vida e que confere sentido à ação; $\mathrm{e}$, por isso, todo jogo tem um significado. Ele [o jogo desportivo] apenas se torna possível quando um influxo da mente, concordância da alma, desmonta o determinismo absoluto do cosmos (HUIZINGA, 2003) mas não altera a sua ordem. O significado (assim como os sentidos) pode, constantemente, ser atualizado; entretanto, há uma raiz significante mais profunda que dirige e, também, ajuda no entendimento da variedade de significados. Ouçamos, então, Costa (2006, p. 37): “[...] o fenómeno desportivo permite-nos estudar o comportamento do homem a partir das suas raízes arcaicas e esclarece-nos sobre o sentido profundo da existência humana".

Como atividade lúdica, simbólica e agônica, o "jogo [desportivo] verdadeiro e espontâneo também pode ser profundamente sério. O jogador pode entregar-se ao jogo de corpo e alma, e a consciência de que se trata 'apenas' de um jogo pode ser relegada para um segundo plano. A alegria inextrincavelmente associada ao jogo pode transformar-se não só em tensão como arrebatamento" (HUIZINGA, 2003, p37). Esse arrebatamento eleva-nos, transporta-nos às esferas do simples e do sublime, do próximo e do inalcançável, do profano e do sagrado, da Unidade e da diversidade; não são lugares comuns. A natureza infantil do lúdico, entretecida com a vitalidade agônica, faz do desporto um meio estratégico de formação da Pessoa Humana, fundamentado numa educação em valores. Essa nota registra a esperança, lançada pelo nosso texto, de restauração do ideal e do sentido de unificação da identidade humana expostos pelo contexto desportivo. A dimensão agônica impele-nos à perfeição física e espiritual; enquanto que a dimensão lúdica, no dizer de Huizinga (2003), está em consonância à capacidade criadora de cultura, devido à possibilidade de desenvolver, em plenitude, as necessidades humanas de ritmo, harmonia, mudança, alternância, contraste, clímax etc. Esse sentido de identidade lúdica e agônica, com toda a sua magia e seu mistério, está ligado a um espírito que aspira à honra, à dignidade, à superioridade e à beleza. Somente a

Movimento, Porto Alegre, v. 17, n. 01, p. 213-235, janeiro/março de 2011. 
experiência transcendente do lúdico (deleite) e do agônico (embate) faz surgir, além das categorias do prazer e da dor, algo ainda maior: o êxtase - um estágio, como disse Monteiro (2007, p. 103), em que "a agonia é apenas a ponta do iceberg lúdico". Assim, não temos medo de afirmar que a linguagem do desporto é a do movimento, do gesto, da ação prática, da alegria contagiante e da luta por um ideal: uma mensagem universal de que a Unidade do humano é possível.

Sócrates, o mais sábio dos mestres clássicos, insistia com os artistas plásticos para que não se contentassem apenas com reproduzir a beleza corpórea, mas que aspirassem também a transmitir a expressão da nobreza do caráter dos homens. Do mesmo modo, a atividade docente na Educação Física não deveria apenas se contentar com o ensino da atividade motora ou desportiva, mas deveria incentivar e levar o jovem a reconhecer, na prática dessas atividades, aquilo que faz a diferença na formação da personalidade, do caráter e da alma.

Afinal, O desporto não é apenas um confronto entre pessoas, agremiações, estados e nações na busca, muitas vezes, irracional por resultados e, portanto, com pouco significado educativo. Ao contrário, os significados, os sentidos e os valores que iluminam a atividade desportiva fazem dela mais do que uma diversão, um lazer e mais do que uma competição agônica: ela é uma via, um caminho, a senda e a conexão com a dimensão do imperecível. O atleta interior é a alma do homem; e este, na sua Unidade, é o protagonista de uma odisseia rumo ao (im)possível, ao (in)tangível, ao seu Lar.

Uma utopia? Pode ser. Mas o desporto deixa de ser utópico quando esgota o campo do possível (BENTO, 1998); e, nesse campo de possibilidades a serem esgotadas, existem fronteiras com novos e bem-aventurados campos: a partir da filosofia do desporto vinculada a reflexões da arte de superação e de transcendência, podemos, de fato ou simbolicamente, ascender à perspectiva Não Dual. É no desporto que a Beleza Original manifesta-se no ato motor, na corporificação das muitas - conhecidas ou não - dimensões humanas e na expressão de identidade de toda a humanidade. Essa talvez seja a substância da aretê eterna, que, na perspectiva de Vaz (2004, p.

Movimento, Porto Alegre, v. 17, n. 01, p. 213-35, janeiro/março de 2011. 
219), é "a excelência do ser que se manifesta no seu operar"; e esse operar no desporto é o desempenho humano em sintonia com o Bem e com o Belo - "o campo do possível" da experiência Não Dual. Tal esfera é composta pelo otimismo, pela paixão, pelo momento, pela fé, pela harmonia e pela beleza que, num momento de coragem e verdade, contempla a imagem da natureza intemporal e, ao mesmo tempo, faz vibrar, pelas cordas dos músculos, dos ossos e de todos os órgãos, a sinfonia de viver.

\section{Considerações finaIS}

As considerações de natureza filosófica visam a buscar, no seio dessa disciplina, contribuições para nos ajudar na problematização, na reflexão e na reatualização da nossa função de educador. Saber que há um ideal de não dualidade é insuficiente para acusar esse ou aquele autor, filósofo, investigador e/ou pensador como dualista, pois entendemos que a nossa relação com o universo objetivo é forçosamente dual; mas, é claro, não precisa ser dualista. Quando sacralizamos o mundo, imediatamente tudo se manifesta numa só Unidade; e, ao dogmatizamos uma determinada posição em relação a esse ou àquele ponto de vista, estamos no terreno que difere da Unidade.

Apresentamos, inicialmente, uma discussão sobre esse tema a partir de pontos de vista extraídos tanto da filosofia oriental como da ocidental para justamente demonstrar a hipótese de unidade do pensamento oriental-ocidental. Acreditamos que considerar a filosofia platônico-socrática como dualista é compreendê-la como um sumário de gêneros opostos e não como distinções integradas e unitárias. Essa análise encerra, na maioria das vezes, uma limitação hermenêutica, pois a interpretação corre o risco de estar distante daquilo que teria sido, de fato, o pensamento de Platão, especialmente quando as nossas fontes não derivam das informações dos textos desse filósofo.

A Paideia Helênica visava à superação de todas as limitações impostas ao homem, como, por exemplo, "eu sou o corpo", "eu sou a

Movimento, Porto Alegre, v. 17, n. 01, p. 213-235, janeiro/março de 2011. 
alma", "eu sou o corpo e alma", ou ainda, "[eu] penso, logo existo", "[eu] sinto, logo existo", entre outras amputações: na verdade tudo está num processo permanente de formação, transformação e transcendência. Por isso, o desporto, as artes, o conhecimento são apenas símbolos que apelam para a identidade da nossa natureza e para o sentido da Vida Humana. A batalha entre os diferentes componentes da arte desportiva é uma representação de uma luta cósmica na qual se busca a vitória sobre os mecanismos que nos levam à ilusão. Visto assim, o desporto, como as outras formas de manifestação humana, é o caminho (Tao) para o autoconhecimento: um apelo à exaltação e à elevação humanas com vistas à conquista e à integração das suas esferas internas e externas.

As nossas meditações sobre o desporto, visto como substrato pedagógico da Paideia, não têm a intenção de apontá-lo como um meio de Unidade (possível) do corpo e sim da Pessoa humana, que, para nós, é a síntese (ou corporificação) viva de diversas dimensões, conhecidas ou não. Assim, apostamos que o desporto pode ser - pelas suas características, pelos seus fundamentos, pelo seu simbolismo, pelos seus valores, pela sua tradição, pelo seu destino e pelos seus sentidos quando livremente escolhido - um meio de se praticar, estudar e entender o Homem por inteiro: uma proposta pedagógica imanente, mas que nos aponta para a transcendência.

$\mathrm{O}$ desporto nutre-se na natureza agônica; é mediado pela categoria lúdica; e, desse modo, atinge o sentido de êxtase, exaltando a tarefa humana como a arte sublime da recriação. Lembramos que Zeus, nutrido pela força agônica, lutou e venceu o seu pai, Cronos, o deus do tempo, dando origem à revolução divina que revelou o universo. Assim, tanto a nossa vida ordinária como a vida desportiva, simbolicamente, são formas de se evidenciar o embate que deu origem à ordem, à harmonia, ao equilíbrio e ao cosmos, e que denota uma ideia de Unidade.

$\mathrm{Na}$ tensão gerada entre o universo da dualidade e o da não dualidade, o desporto desponta como um elo que nos une a todos e nos convida a viver uma filosofia da prática da totalidade: o ideal da Paideia. Finalmente, os pontos que convergem para uma orientação

Movimento, Porto Alegre, v. 17, n. 01, p. 213-35, janeiro/março de 2011. 
unitária, nas diferentes abordagens circunscritas no texto, são os seguintes: yin e yang (dualidade), origem e destino Tao (Unidade), a tríade taoísta; Atman e Jiva são as manifestações (dvaita) da Unidade Brahman (advaita); o sensível (ousía divisível), alma cósmica (ousía entre o divisível e o indivisível) e inteligível (ousía indivisível), a tríade platônica; Pai, Filho e Espírito Santo são a Santíssima Trindade do mundo cristão. O fundamento do Ser (Pai, Tao, Inteligível, Brahman) é a Unidade, Unitas: a humanitas. Se tivermos serenidade e sensibilidade, ultrapassando as diferenças, podemos perceber a Unidade em tudo. Por isso, não podemos deixar de especular que, talvez, na sua expressão humanitas, o desporto possa apresentar a sua essência potencialmente única e diversa, a trindade da superação dos desafios: o agon, o lúdico e o êxtase.

Movimento, Porto Alegre, v. 17, n. 01, p. 213-235, janeiro/março de 2011. 


\begin{abstract}
Sport, Paideia and Nonduality
Abstract: The present essay has the intention of presenting a discussion, based on the (Eastern and Western) conceptual and philosophical contribution, about the spheres of duality and nonduality: to reflect, from a triad vision restricted to the different philosophical principles, on the ideas and concepts that guide for the Unit. The Platonic-Socratic philosophy is the basis of our meditations and, particularly, of the evidence of Unity associated with the Paideia. We suggest the sport education, by means of its symbolic extract, as a practice than can construct a possible Unit
\end{abstract}

Keywords: Sports. Philosophy. Education.

Deporto, Paideia y No-dualad

Resumen: El presente ensayo tiene la intención de presentar una discusión, a partir de las contribuciones conceptuales y filosóficas (oriental y occidental), sobre las esferas de la dualidad y la no-dualidad: reflexionar, desde una visión tríade circunscrita en los diferentes principios filosóficos, sobre las ideas y los conceptos que orientan para la Unidad. La filosofía platónicosocrática es la base de nuestras meditaciones y, particularmente, de los indicios de Unidad asociados a la Paideia. Sugerimos la educación deportiva, por intermedio de su extracto simbólico, como una práctica que puede construir una Unidad posible.

Palabras clave: Deportes. Filosofía. Educación

\title{
REFERÊNCIAS
}

ADORNO, Francesco. Sócrates. Lisboa: Edições 70, 2002.

BENTO, Jorge Olímpio. Desporto: discurso e substância. Porto: Campo das Letras, Universidade do Porto, 2004. 1998

Desporto e humanismo: o campo de possível. Rio de Janeiro: Ed. UERJ,

Pedagogia do desporto: definições, conceitos e orientações. In: TANI, Go; BENTO, Jorge Olímpio; PETERSEN, Ricardo. Pedagogia do desporto, Rio de Janeiro: Guanabara Koogan, 2006. p. 3-97.

BLACKBURN, Simon. Dicionário Oxford de filosofia. Rio de Janeiro: Jorge Zahar, 1997.

Wovimento, Porto Alegre, v. 17, n. 01, p. 213-35, janeiro/março de 2011. 
BOFF, Leonardo. Saber cuidar: ética do humano, compaixão pela terra. Petrópolis: Vozes, 2000a.

Tempo de transcendência: o ser humano como um projecto infinito. Rio de Janeiro: Sextante, 2000b.

CAMPBELL, Joseph. Mito e transformação. São Paulo: Ágora, 2008.

CHURCHLAND, Paul. Matéria e consciência: uma introdução contemporânea à filosofia da mente. São Paulo: Editora UNESP, 2004.

COSTA, António. À volta do estádio: o desporto, o homem e a sociedade. Porto: Campo das Letras 1997.

. Desporto e Antropologia. In: PEREIRA, A.; COSTA, A.; Garcia, R. O desporto entre lugares. Porto: Faculdade de Desporto da UP, 2006. p. 37-72.

ELIADE, Mircea. O sagrado e o profano: a essência das religiões. São Paulo: Martins Fontes, 2001.

FERNANDES, Ana. A poética do desporto em Maurice Genevoix. In: OLIVEIRA, F. O espírito olímpico no novo milênio. Coimbra: Imprensa da Universidade de Coimbra, 2000. p. 197-204.

FERNÁNDEZ, Enrique. La Dimensión Épica del Deporte. Revista de Ciencia de la Actividad Física y del Deporte, Murcia, v. 1, n. 1, p. 38-40, 2004.

FERRY, Luc. Aprender a Viver. Rio de Janeiro: Objetiva, 2007.

GARCIA, Rui Proença. Olimpismo: um apelo à transcendência humana. Belo Horizonte: EEFFTO-UFMG, Casa da Educação Física, 2006.

HUIZINGA, Johan. Homo ludens. Lisboa: Edições 70, 2003.

JAEGER, Werner. Paidéia: a formação do homem grego. São Paulo: Martins Fontes, 2003.

KITTO, Humphrey Davey. Os gregos. Coimbra: Arménio Amado, 1990

KUSHNER, Kenneth. O arqueiro zen e a arte de viver. São Paulo: Pensamento, 1988.

LAO TSÉ. Tao Te Ching. São Paulo: Martim Claret, 2001.

MONTEIRO, Alberto. Desporto: da excelência à virtude (ARETÉ), um caminho de vida. Tese de Doutoramento. UM, 2007.

PATRÍCIO, Manuel. Perenidade da aretê como horizonte apelativo da Paidéia: sobre a excelência na educação. In: CONGRESSO INTERNACIONAL DA CASA DA EDUCAÇÃO FÍSICA, Belo Horizonte, 2005. [Anais...]

PLATÃO. Fredo. Tradução Luis Gil Fernández. Madrid: Alianza, 1995.

Movimento, Porto Alegre, v. 17, n. 01, p. 213-235, janeiro/março de 2011. 
Leis. Tradução Carlos Humberto Gomes. Lisboa: Edições 70, 2004.

Protágoras. Tradução Ana da Piedade Elias Pinheiro. Lisboa: Relógio D’Água, 1999.

A república. Tradução Maria Helena da Rocha Pereira. Lisboa: Calouste Gulbenkian,1996.

Timeu. Tradução Maria José Figueiredo. Lisboa: Instituto Piaget, 2003.

REALE, Giovanni., ANTISERI, Dario. Historia del pesamiento filosófico y cientifico: antigüedad y edad media. Barcelona: Herder, 1991. v. 1.

REIS, Maria Dulce. Por uma nova interpretação das doutrinas escritas: a filosofia de Platão é triádica. Kriterion, Belo Horizonte, v. 48, n.116, p. 379-398, dez. 2007.

SÃO JOÃO, 14, 6. In: BÍBLIA Sagrada. Versão dos textos originais. Lisboa: Difusora Bíblica, 2003. p. 1758.

SANFORD, John. A jornada da alma. São Paulo: Paulus, 1998.

SANTOS, Boaventura de Souza. A Crítica da Razão Indolente. Contra o desperdício da experiência. Porto: Afrontamento, 2000.

SANTOS, Mário Ferreira. Platão: o um e o múltiplo. São Paulo: IBRASA, 2001.

TILAK, Swami. Néctar do guita. Rio de Janeiro: ERCA, [197?].

URBANO, Carlota. O canto do martírio: espírito agónico no humanismo. In: OLIVEIRA, F. O espírito olímpico no novo milênio. Coimbra: Imprensa da Universidade de Coimbra, 2000. p. 183-195.

VAZ, Henrique. Antropologia filosófica. São Paulo: Loyola, 2004.

WATANABE, Lygia Araujo. Platão: por mitos e hipóteses. São Paulo: Moderna, 2006.

WATTS, Alan. TAO: o curso do rio. São Paulo: Pensamento, 1975.

XENOFONTE. Ditos e feitos memoráveis de Sócrates. Tradução Edson Bini. São Paulo: Edipro, 2006

Movimento, Porto Alegre, v. 17, n. 01, p. 213-35, janeiro/março de 2011. 